\title{
Burning mouth syndrome responsive to pramipexol
}

\author{
J. Stuginski-Barbosa • G. G. R. Rodrigues • \\ M. E. Bigal · J. G. Speciali
}

Received: 7 September 2007 / Accepted: 25 November 2007/Published online: 25 January 2008

(C) Springer-Verlag 2008

\begin{abstract}
Burning mouth syndrome (BMS) is characterized by burning discomfort or pain in otherwise normal oral mucosa. It is usually refractory. Treatment modalities are scarce. Herein we report one case of primary disabling BMS, previously refractory to multiple regimens, with complete and persistent improvement with pramipexol, a nonergot dopamine agonist which has high selectivity for dopaminergic D2 receptors. We discuss potential pathophysiological implications of our findings.
\end{abstract}

Keywords Orofacial pain - Burning mouth syndrome . Pramipexol

$\begin{array}{ll}\text { Abbreviations } \\ \text { BMS } & \text { Burning mouth syndrome } \\ \text { RLS } & \text { Restless leg syndrome } \\ \text { PD } & \text { Parkinson disease }\end{array}$

\section{Introduction}

Burning mouth syndrome (BMS) is defined as the sensation of burning or pain on the oral mucous membrane, without

J. Stuginski-Barbosa · G. G. R. Rodrigues $\cdot$ J. G. Speciali

The Department of Neurology, School of Medicine

at Ribeirão Preto, Ribeirão Preto, SP, Brazil

M. E. Bigal

Neurology, The Albert Einstein College of Medicine,

Bronx, NY, USA

J. G. Speciali $(\bowtie)$

Hospital das Clínicas de Ribeirão Preto, Avenida Bandeirantes, 3900, Ribeirão Preto, SP 14400-000, Brazil

e-mail: speciali@netsite.com.br evidence of abnormalities in the direct inspection, clinical exam or subsidiary investigation [1]. Besides pain and tingling, BMS is often characterized by dry mouth and taste perversion [1,2]. BMS is more prevalent among postmenopausal women, affecting from 1.5 to $5.5 \%$ of this population [3].

The BMS is a primary diagnosis. Several factors are reported as being associated with burning mouth symptoms, including xerostomy, allergies to dentistry materials, oral candidiasis, systemic nutritional deficiency (e.g. vitamin B1, B2, B12, folic acid and zinc), diabetes, hormonal disturbances, oral ulcer and periodontitis [1]. Nonetheless, diagnosis of BMS requires the exclusion of secondary causes.

Some studies suggest that BMS is a specific form of cranial neuropathy, based on the pattern of sensorial findings (hypoesthesia) [4], reduction of the nociceptive threshold [5], as well as on neurophysiologic findings (suggestive of a small fiber neuropathy) [6]. Other studies suggest central nervous system abnormalities, including changes in the blink reflex [7], larger availability of dopamine receptors in the putamen [8] and reduction of 6$\left[{ }^{18} \mathrm{~F}\right]$ fluorodopa recaptation on putamen [9].

The therapeutic options for BMS are scarce. Anecdotal reports suggest the benefit of alfa-lipoic acid, an antioxidant used in diabetic neuropathy, amisulpiride, a neuroleptic of second generation that in low dosages presents dopaminergic activity, and of topic clonazepam [10 13]. A recent study suggested that gabapentin is not effective in the treatment of BMS [14].

Herein we report one case of refractory BMS with complete improvement with pramipexol, a non-ergotic dopaminergic agonist commonly used for Parkinson's disease. As exposed below, this medication was chosen based on some clinical features of our patient that 
resembled what is commonly seen in restless leg syndrome. Pramipexol has not been previously reported as potentially effective for BMS. Accordingly, because the patient was very refractory, and also because of some peculiar clinical findings, we speculate on the pathophysiology of the disease.

\section{Case report}

A 68-year-old woman reported daily continuous burning feeling on the lateral and anterior site of her tongue and lower lip for 3 years. The burning was of moderate intensity (7 on a 10-point visual analogical scale), worsening by the end of the afternoon. She reported important improvement when speaking and moving the lower lip, as well as when drinking cold water. She didn't report any worsening factor associated with worsening of the burning. She noticed change in her taste sense, with lower tolerance to heavy meals and increased burning after acid meals. She did not complain of xerostomia and therefore the salivary flow rate was not measured. She denied other medical antecedents or use of medication.

Over the past 3 years, before seeking care with us, the patient previously consulted four gastroenterologists. She was submitted to a gastroscopy and Helicobacter pylori infection was found. She had no improvement of the burning sensation after proper treatment (Table 1).

The patient also had consulted five dentists. They changed her dental prosthesis twice, tried periodontal treatment and artificial saliva without meaningful results.

The intraoral inspection was normal. She used wear superior total denture and inferior removable partial denture, both in good conditions, without vertical dimension lose or instability. She had no caries or periodontal diseases in the anterior inferior teeth. Periapical and panoramic Xray exams were performed without alterations. General physical and neurological exams were unremarkable.

Blood analysis was performed and blood routine, as well as screening for vitamin deficiencies and ferritin were within normal limits.

Table 1 Diagnostic criteria for burning mouth syndrome according the International Classification of Headache Disorders (2004) [24]

\section{Description:}

An intraoral burning sensation for which no medical or dental cause can be found.

Diagnostic criteria:

(a) Pain in the mouth present daily and persisting for most of the day.

(b) Oral mucosa is of normal appearance.

(c) Local and systemic diseases have been excluded.
We established a diagnosis of refractory BMS and initiated treatment with pramipexol $(0.125 \mathrm{mg}$ at night—see discussion for reasons that motivated the choice). Followup information was obtained prospectively using a headache calendar (measuring frequency and severity of pain, use of rescue medications, etc.) and was contrasted to the baseline. The information was independently reviewed by one of us (JGS). After 1 week of treatment the patient reported a $20 \%$ improvement (a decrease from seven to five on visual analogical scale) and around $25 \%$ diminution in the frequency of the symptoms. The dose was slowly increased to $0.75 \mathrm{mg}$ at night. After 4 weeks of treatment, the burning symptoms disappeared. She remained symptom free for several months. She did not report side effects. Upon withdrawal of pramipexol, the symptoms relapsed around 6 days after, with an intensity of pain around $60 \%$ of the baseline. Since then, she has been using $0.75 \mathrm{mg}$ at night, with total control of the burning sensation. The patient was followed for a year and she remains pain free, with no significant tolerability issues.

\section{Comments}

This case of BMS showed two peculiar clinical characteristics: (1) it worsened by the end of the day; (2) it improved with the movement of the tongue. The circadian fluctuation of the symptoms is a known feature of the BMS [15]; however, the relief by moving the tongue is not a notorious manifestation of this disease. Therefore, this pattern of symptoms seemed similar to what is seen in restless leg syndrome (RLS), a condition secondary due to a dopaminergic dysfunction of the central nervous system. RLS is characterized by lower limbs dysesthesias that worsen by the end of the day and improve when moving the legs $[16,17]$. The prevalence of RLS in patients with headache is high, [18], however, there are no data correlating RLS with BMS.

Although the relationship between BMS and Parkinson's disease is not universally accepted, the comorbidity has been suggested. BMS is frequent among patients with Parkinson's disease (PD). In a study of 115 patients with $\mathrm{PD}$, burning mouth happened in $24 \%$ of them, incidence prevalence 30 times greater than expected by chance only [19].

The dopaminergic and nigrostriatal pathways are important on pain modulation [20-22]. Non-specific disturbances on the dopaminergic system have been documented in patients with BMS $[8,9]$. The association of BMS with RLS and PD, besides the improvement with amisulpiride [11], point to a dopaminergic dysfunction in BMS. All these facts support our therapeutic choice for the reported case. Pramipexol is a non-ergotic dopaminergic 
agonist, with predilection to dopaminergic D-2 receptors $[23,24]$. Our anedoctal finding should be confirmed by a pilot study, and, if positive, by clinical trials. As a cautionary note, since this is a report of a single case, we cannot exclude that the therapeutic response to pramipexol happened as a placebo effect, or merely as a coincidence.

Conflicts of Interest None.

\section{References}

1. Grushka M, Epstein JB, Gorsky M (2002) Burning mouth syndrome. Am Fam Physician 65:615-620

2. Grushka M, Ching V, Epstein J (2006) Burning mouth syndrome. Adv Otorhinolaryngol 63:278-287

3. Riley JL 3rd, Gilbert GH, Heft MW (2002) Orofacial pain: racial and sex differences among older adults. J Public Health Dent 62(3):132-139

4. Forssell H, Jääskeläinen SK, Tenovuo O, Hinkka S (2002) Sensory dysfunction in burning mouth syndrome. Pain 99:41-47

5. Svensson P, Bjerring P, Arendt-Nielsen L, Kaaber S (1993) Sensory and pain thresholds to orofacial argon laser stimulation in patients with chronic burning mouth syndrome. Clin J Pain 9:207-215

6. Lauria G, Majorana A, Borgna M et al (2005) Trigeminal smallfiber sensory neuropathy causes burning mouth syndrome. Pain 115:332-337

7. Jääskeläinen SK, Forssell H, Tenovuo O (1997) Abnormalities of the blink reflex in burning mouth syndrome. Pain 73:445-460

8. Hagelberg N, Forssell H, Rinne JO et al (2003) Striatal dopamine D1 and D2 receptors in burning mouth syndrome. Pain 101:149154

9. Jääskeläinen SK, Rinne JO, Forssell H et al (2001) Role of the dopaminergic system in chronic pain-a fluorodopa-PET-study. Pain 90:257-260

10. Zakrzewska JM, Forssell H, Glenny AM (2006) Interventions for the treatment of burning mouth syndrome (Cochrane Review). In: The Cochrane Library, Issue 1. Oxford: Uptade

11. Femiano F, Gombos F, Scullyu C, Busciolano M, De Luca P (2000) Burning mouth syndrome (BMS): controlled open trial of the efficacy of alpha-lipoic acid (thioctic acid) on symptomatology. Oral Dis 6:274-277
12. Bogetto F, Bonatto Revello R, Ferro G, Maina G, Ravizza L (1999) Psychopharmacological treatment of burning mouth syndrome (BMS). A study on a sample of 121 patients. Minerva Psichiatr 40:1-10

13. Gremeau-Richard C, Woda A, Navez ML et al (2004) Topical clonazepan in stomadynia: a randomised placebo-controlled study. Pain 118:51-57

14. Heckmann SM, Heckmann JG, Ungethum A, Hujoel P, Hummel $T$ (2006) Gabapentin has little or no effect in the treatment of burning mouth syndrome-results of an open-label pilot study. Eur J Neurol 13(7):e6-e7

15. Allen R, Picchietti D, Hening WA et al (2003) Restless legs syndrome: diagnostic criteria, special considerations and epidemiology. A report from the restless legs syndrome diagnosis and epidemiology workshop at the National Institutes of Health. Sleep Med 4:101-119

16. Clemens S, Rye D, Hochman S (2006) Restless legs syndrome: revisiting the dopamine hypothesis from the spinal cord perspective. Neurology 67:125-130

17. Young WB, Piovesan EJ, Biglan KM (2003) Restless legs syndrome and drug-induced akathisia in headache patients. CNS Spectr 8(6):450-456

18. Clifford TJ, Warsi MJ, Burnett CA, Lamey PJ (1998) Burning mouth in Parkinsońs disease sufferers. Gerodontology 15(2):7378

19. Hagelberg N, Jääskeläinen SK, Martikainen IK, Mansikka H, Forssell H, Scheinin H, Hietala J, Pertovaara A (2004) Striatal dopamine D2 receptors in modulation of pain in humans: a review. Eur J Pharmacol 500:187-192

20. Altier N, Stewart J (1999) The role of dopamine in the nucleus accumbens in analgesia. Life Sci 65:2269-2287

21. Kotecha SA, Oak JN, Jackson MF, Perez Y, Roser BA, van Tol $\mathrm{NH}$ et al (2002) A D2 class dopamine receptor transactivotes a receptor kinase to inhibit NMDA receptor transmission. Neuron 35:1111-1122

22. Bennett Jr JP, Piercey MF (1999) Pramipexole—a new dopamine agonist for the treatment of Parkinson's disease. J Neurol Sci 163:25-31

23. Vallone D, Picetti R, Borelli E (2000) Structure and function of dopamine receptors. Neurosci Biobehav Rev 24:125-132

24. Headache Classification Committee of the International Headache Society (2004) Classification and diagnostic criteria for headache disorders, cranial neuralgias, and facial pain. Second edition. Cephalalgia 24[Suppl 1]:1-160 